\title{
Architect Max Zucker - regionalist or modernist? Designs from the Prut valley in the Hutsul region
}

\author{
Jacek Czubiński
}

jacek.czubinski@wp.pl

Institute of the History of Architecture and Conservation of Monuments, Kraków University of Technology

\begin{abstract}
The article presents the little-known but extremely interesting work of architect Max Zucker in the spa towns located in the Prut valley in the Hutsul region in the inter-war period. Research results allow us to call him an author of around 20 objects. His work was connected with various stylistic tendencies: historical, classicistic, regional, modernist forms. Projects connected with modernism are particularly important. He can be considered an informal creator and a consistent implementer of the phenomenon aimed at identifying the identity of Hutsul modernist architecture.
\end{abstract}

Keywords: Modernist architecture, regional architecture, Hutsul region, Max Zucker, Prut river, spa architecture.

\section{Introduction}

The architecture of the inter-war period in spa resorts in the Prut valley in the Hutsul region was characterised by a great diversity. The dominant tendency was regionalism in various forms: alpine, Zakopane, Hutsul and Galician styles and their compilations. Architecture was looking for a national style - from manor style to classicizing trends. At the end of the 20s modernism appeared in the international style with elements of naval style, functionalism and art déco motives [Czubiński 2008]. Many objects were destroyed during World War II and in the post-war period; the process of destruction still continues. Nevertheless, a representative group of buildings from this period has been preserved to this day. Max Zucker designed many of them. Research results allow us to call him an author of around 20 objects $^{1}$. The aim of the article is to present a little-known but extremely interesting work of this architect ${ }^{2}$. Research results allow us to call him an author of around 20 objects $^{3}$. The aim of the article is to present the works of this architect, which is not widely known but extremely interesting ${ }^{4}$.

\section{The character of Max Zucker}

At the current stage of research, little is known about the architect himself. He was born in Lviv, probably in the 90s in the Jewish family [Yad Vashem, Item ID 1246335]. His wife was Berta Zucker née Salzberg, born in 1893

1 The author has been conducting research on spa architecture in the villages located in the Upper Prut Valley in the Hutsul region for several years at the Institute of the History of Architecture and Conservation of Monuments of the Kraków University of Technology, together with the employees of the Institute of Tourist Architecture at the Ivano-Frankivsk National Technical University of Oil and Gas.

2 No scientific work related to this architect has been published so far.

3 The author has been conducting research on spa architecture in the villages located in the Upper Prut Valley in the Hutsul region for several years at the Institute of the History of Architecture and Conservation of Monuments of the Kraków University of Technology, together with the employees of the Institute of Tourist Architecture at the Ivano-Frankivsk National Technical University of Oil and Gas.

4 No scientific work related to this architect has been published so far. 
also in Lviv, with whom he had several children [Yad Vashem, Item ID 1246293]. We believe that he graduated architecture at the Lviv Polytechnic in the 20s, he lived with his family in Jaremcze in his own house at ul. Liepkowa 1. He was murdered by the Nazis in Delatyn in 1941 or $1942^{5}$.

Max Zucker was a certified architect. He signed his designs with stamps of various content, including $M$. ZUCKER, government-authorised builder. Sworn court expert or M. ZUCKER, government-authorised architect, sworn court expert. This may indicate successive acquisition of further powers. He was involved in designing but also performed the function of construction manager. His documented activity is connected with towns located in the upper Prut. The research carried out does not allow to determine whether he had projects realized in another area. His work was characterised by stylistic duality of regional and modernist forms.

\section{Projects and realizations}

Many of the objects designed by Max Zucker have not survived. They are only known thanks to archival designs. Fortunately, many buildings have survived to this day. Objects and designs will be presented in groups related to various stylistic tendencies occurring in the architect's works: historical, classicistic, regional, modernist forms, and compiling the last two tendencies. For this reason, the chronology of their creation will not always be preserved.

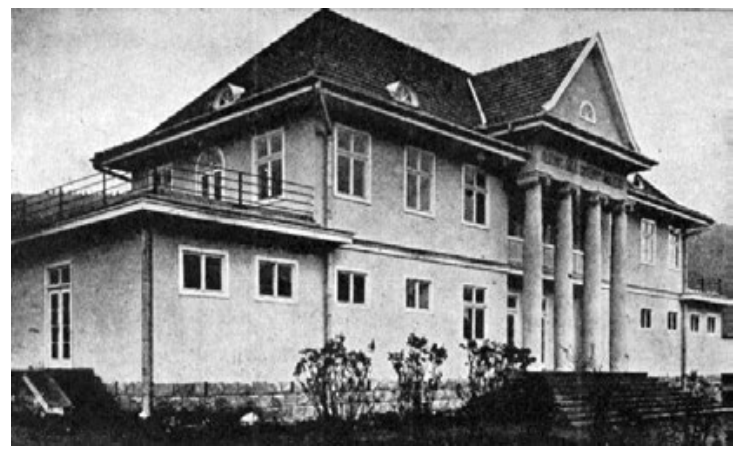

Fig. 1. Jaremcze. Bathing facility of dr Józef Matuszewski. Design: Max Zucker, 1935. Postcard from 1930s from the author's collection

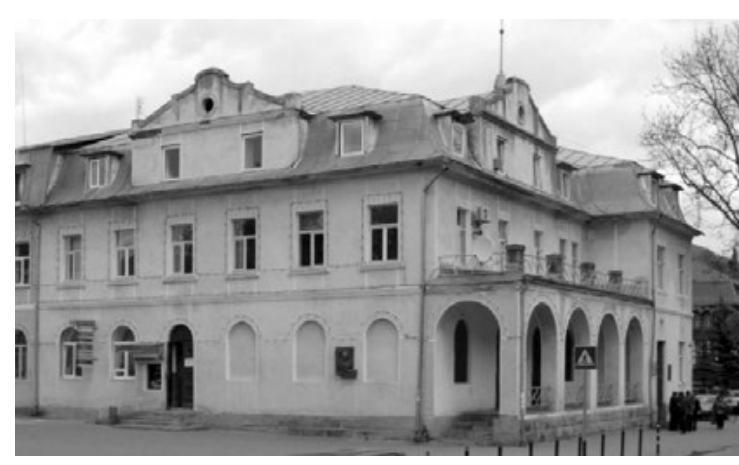

Fig. 2. Jaremcze. The building of the former Hanusa hotel. Photo.: Jacek Czubiński 2010

The first known object designed by Max Zucker was the bathing building for dr Józef Matuszewski from 1927. It was a multi-storey stone building with a functional attic and roof covered with tiles. It was equipped with very modern installations. It had its own boiler room providing hot utility water and central heating as well as heated mud used for healing treatments. It is known only from the original technical description, which does not contain any information about its architectural expression [DAIFO, ref. no. 2450]. In 1935, the second project of the bathing facility of dr Józef Matuszewski was created in Jaremcze [DAIFO, ref. no. 2450]. It was a large wooden building, not preserved until today, covered with a high hip roof (Fig. 1). The two-storey object's body is flanked on the sides with single-storey annexes with terraces on the roofs. The symmetrical main façade with a simple composition had a central avant-corp with a classical columned entrance portico crowned with a triangular tympanum ${ }^{6}$. The building is a good example of the monumentalization of modernism through the introduction of classical elements. Forms based on historical styles also appeared on the expansion of the Hanusa hotel in Jaremcze [DAIFO, ref. no. 665]. The project from 1930 provided for the enlargement of the building with a new wing located along the main street. The dimensions and stylistics of the new part have

5 A group of over a dozen projects is stored in the State Archives of Ivano-Frankivsk Oblast in Ivano-Frankivsk, further DAIFO, various signatures.

6 The extension of the building with a new wing was designed in 1935 by architect Tadeusz Noskiewicz from Stanisławów. We now believe that this project has not been implemented. 
been adapted to the existing eclectic character of the architecture of the old building (Fig. 2). Only a part of the project was realized, with two window axes in direct contact with the building being extended.

A large group of projects are wooden buildings with the features of regional architecture in the Hutsul style convention. The design of the extension of the guesthouse of Salamon and Zofia Langsner in Worochta comes from 1929 [DAIFO, ref. no. 406]. The volume of the existing building has been doubled. A large, two-storey building was built on a rectangular plan covered with a steep roof (Fig. 3). A central veranda avant-corp with a triangular tympanum appeared in the front façade. Details related to the regional style.

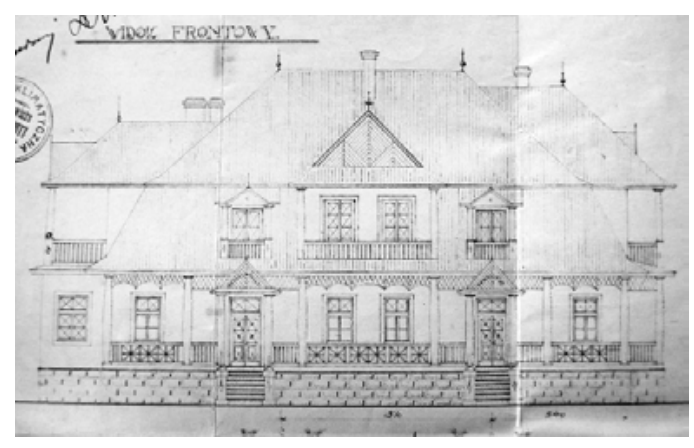

Fig. 3. Max Zucker. The design of the house of Salamon and Zofia Langsner in Worochta, 1929 [DAIFO, ref. no. 406)

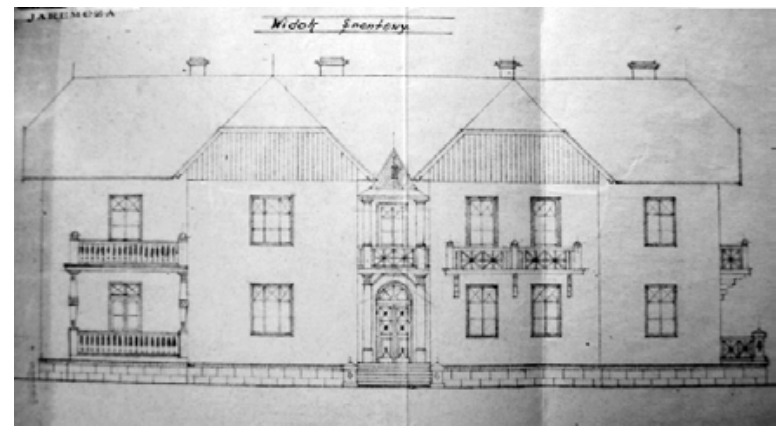

Fig. 4. Max Zucker. Project for extension of Edward Stenzel's villa in Jaremcze, 1929 (DAIFO, ref. no. 664)

In the same year we find the project of the extension of the one-storey villa - a guesthouse for dr Edward Stenzel in Jaremcze. The building permit was issued in 1930 [DAIFO, ref. no. 664]. An eastern part with an irregular projection has been designed for the existing building (Fig. 4). As a result, the front elevation obtained almost symmetrical character with respect to the two-storey entrance porch.

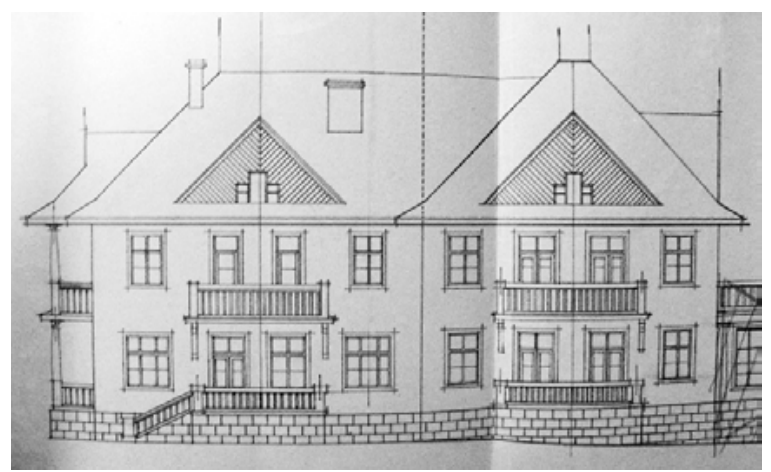

Fig. 5. Max Zucker. Project for extension of the guesthouse of Władysław and Ksawera Lankosz in Jaremcz-Jamna, 1935 (DAIFO, ref. no. 2385)

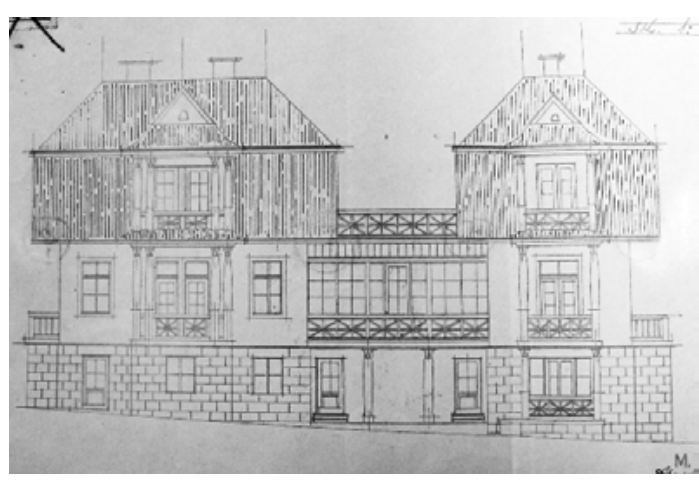

Fig. 6. Max Zucker. Project for extension of the former guesthouse "Marzenie": for Waleria Smólska in Tatarów, year unknown (DAIFO, ref. no. 2831)

Another project from 1930 is associated with the construction of a guest house with a restaurant for Władysław Lankosz in Jaremcze-Jamna. Designs of this building have not been preserved. Authorship can be attributed to Zucker based on the analysis of documents related to project approval and obtaining a construction permit in 1931 [DAIFO, ref. no. 2215]. He also designed the extension of this building in 1935, when Ksawera Lankosz decided to enlarge the guesthouse [DAIFO, ref. no. 2385]. The architect added a new part to the existing building, repeating the elevation composition from the 1930 project (Fig. 5).

Permission for the construction of the "Marzenie" ${ }^{\text {"7 }}$ guesthouse in Jaremcze for Maria Żakowa née Karpowicz was obtained in 1931 [DAIFO, ref. no. 2281]. The construction was completed in 1933. The projection was based on a square shape. The one-storey building with a high stone pedestal is covered with a mansard roof. 
In each façade, two-storey avant-corp with verandas has been designed. Later (the exact date is unknown), the guesthouse was purchased by Valeria Smólska. The new owner asked Zucker to expand the building [DAIFO, ref. no. 2831]. As a result, an object consisting of two connected asymmetrical blocks was created (Fig. 6). The single-axis new part was designed in analogy to the previously existing one. Central, lower than the others, entrance part has a columnar portico on the ground floor. Above the portico there is a glazed veranda with a roof terrace.

In the regional forms, a small villa "Muszka" was designed in 1937 in Jaremcze for Raczyński (first name unknown) (Fig. 8) [DAIFO, ref. no. 2648] ${ }^{8}$.

The last example of this trend is the design of a villa - guesthouse for M. Rosner (first name unknown) in Tatarów (1939) [DAIFO, ref. no. 2704]. A one-storey building with a high roof is based on a rectangular plan with verandas in three elevations. Entrance to the building leads through a column portico that is designed in the axis of the front elevation and is highlighted with a dormer topped with a tympanum.

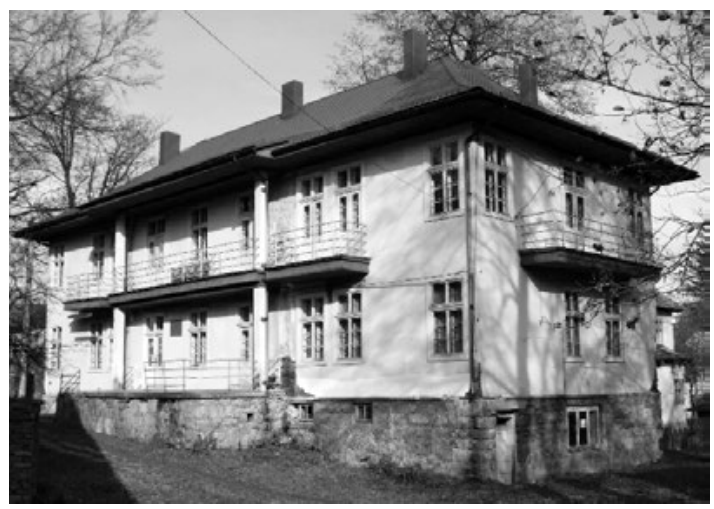

Fig. 7. Jaremcze. "Gena" guesthouse. Photo.: Jacek. Czubiński, 2013

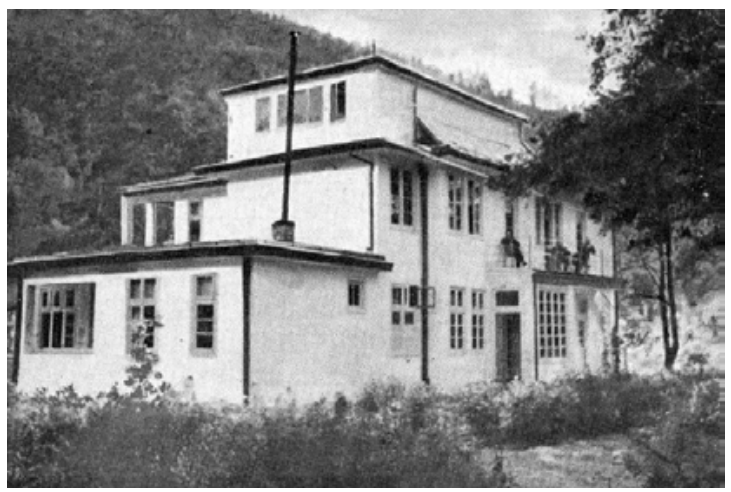

Fig. 9. Jaremcze. Former guesthouse of Maria Rawicka and Janina Friedmanowa, view from the North West. Postcard from 1960s from the author's collection

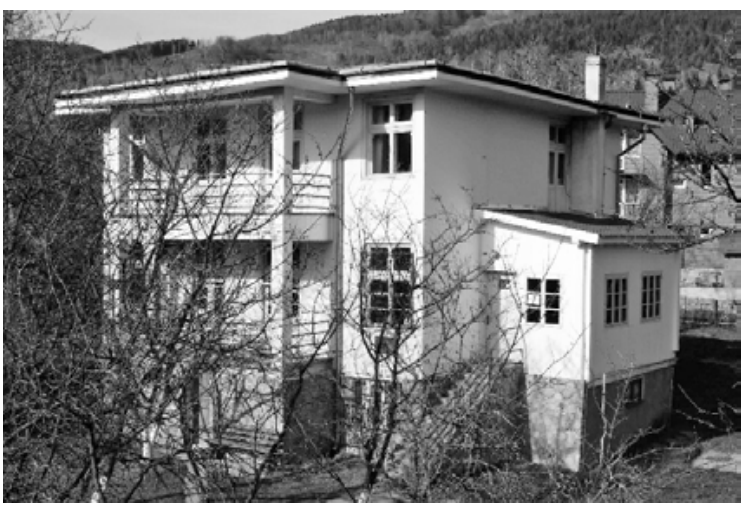

Fig. 8. Jaremcze. Former guesthouse "Przystań", currently building of the court. Photo.: Jacek. Czubiński, 2012

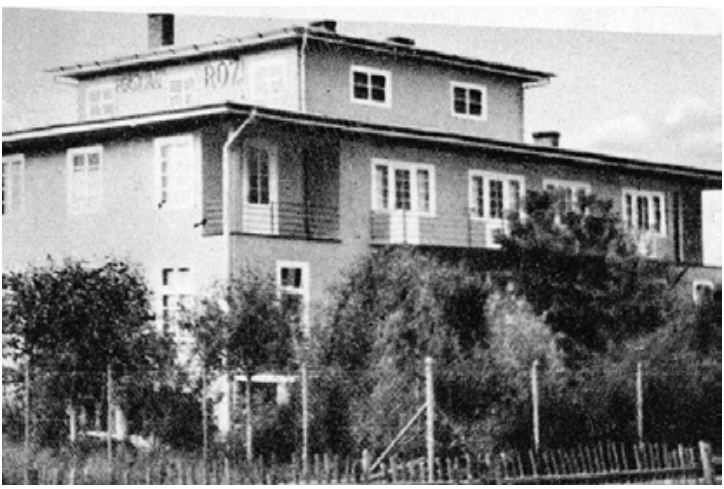

Fig. 10. Jaremcze. "Róż" guesthouse. Postcard from late 1930s from the author's collection

Modernist forms in the work of Max Zucker appeared in the early 30s. The earliest example of this is the design of the "Gena" guesthouse made in 1932 for Antoni Zapletal. The building, approved for implementation in March 1933, is covered with a high hip roof [DAIFO, ref. no. 334]. The whole object has a distinct modernist character. The main façade has a simple two-storey entrance portico. Metal balustrades of balconies and floors give the building a horizontal expression. Corner windows appeared. We can also notice the influences of the 
Art Deco architecture in the form of triangular peaks in the front and side elevations. The building exists to this day, the attic was removed in 2012 (Fig. 7).

The design of a villa for Judy Freund in Jaremcze from 1932 definitely shows a modernistic expression [DAIFO, ref. no. 2336]. After the construction was completed in 1934, the function was changed into a guesthouse named "Przystań" (Fig. 8). Projection of the building is based on a square plan with a two-storey veranda avantcorp in the front elevation and an entry avant-corp from the east. It is covered by a nearly flat roof. The block, symmetrical elevations and details have a clearly geometric character. Corner windows and terrace on the roof of the entrance avant-corps were designed.

The features of mature modernism ware evident in the design of guesthouse for Maria Rawicka and Janina Friedmanowa in Jaremcze from 1934, which no longer exists (Fig. 9). It was approved for realization in August 1935. [DAIFO, ref. no. 2333]. The cubic shape is characterized by the simplicity of the composition. The building has a clearly horizontal character consistently underlined by the horizontal arrangement of balconies and terraces located in the eastern elevation on the river side.

In 1937 the architect created the design of now non-existing "Róż" guesthouse for Ulman (first name unknown) in Jaremcze [DAIFO, ref. no. 2538]. The building is typical for the architect's modernist artwork. There are terraces on the ground floor, continuous balconies on the first floor and corner loggias (Fig. 8).

The next two examples perfectly illustrate the design duality of Max Zucker. We can admire the architect's efficiency in operating with both modernist and regional forms in the same building.

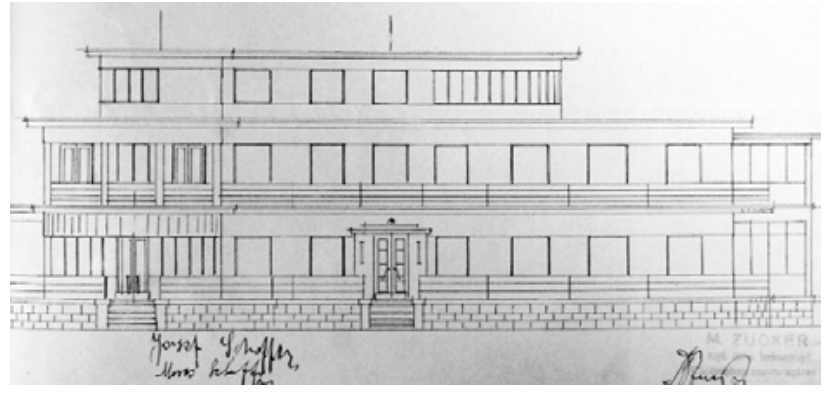

Fig. 11. Max Zucker. Project for extension of the guesthouse of Moros and Józef Schaffer in Tatarów - modernistic version, 1937 (DAIFO, ref. no. 2458)

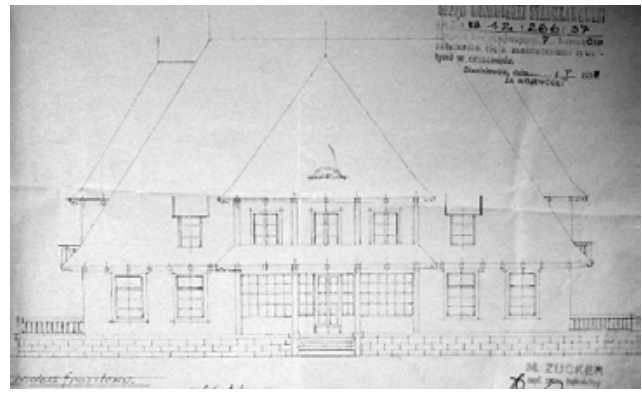

Fig. 12. Max Zucker. Project for extension of the guesthouse of Moros and Józef Schaffer in Tatarów - modernistic version, 1937 (DAIFO, ref. no. 2458)

In 1937, a guesthouse for Moros and Józef Schaffer in Tatarów was designed [DAIFO, ref. no. 2458]. The architect presented to the investors two versions of the building: with modernist and regional features. The first one represented forms of mature modernism with features of naval style in projection roundings (Fig. 11). Horizontal nature of the three-storey building was emphasised by the continuous arrangement of balustrades on terraces and balconies of the first floor. This design seems to be the most consistent implementation of the principles of international style in the architect's works. The investors, however, chose the second version with a high roof and architectural details maintained in regional stylistics (Fig. 12). The building exists to this day.

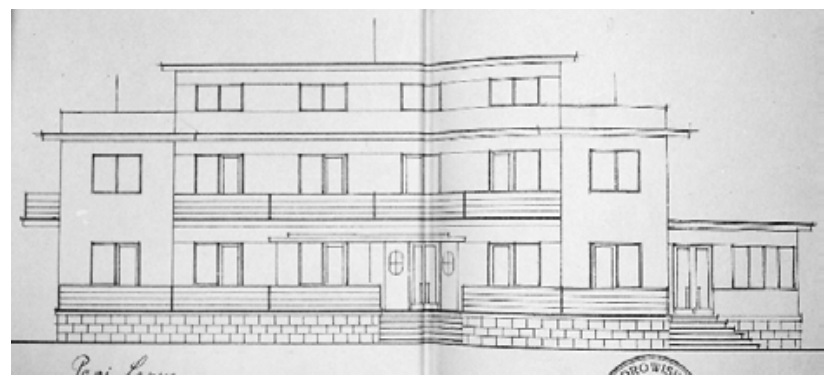

Fig. 13. Max Zucker. Project for extension of the guesthouse of Pepi Lappe in Jaremcze - modernistic version, 1937 (DAIFO, ref. no. 2536)

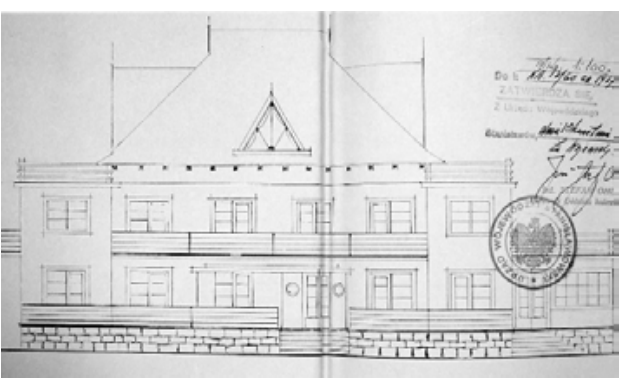

Fig. 14. Max Zucker. Project for extension of the guesthouse of Pepi Lappe in Jaremcze - regional version, 1937 (DAIFO, ref. no. 2536) 
In the same year Max Zucker designed a guesthouse for Pepi Lappe in Jaremcze [DAIFO, ref. no. 2536). Again, two versions were created (Fig. 13, 14). A situation similar to the previous one occurred. The design with modernist features was rejected by the investor, who chose the regional version.

Designs from the late $30 \mathrm{~s}$ are a manifestation of a stylistic compromise. We see an attempt to synthesize regional architecture with modernism. They were not realized due to the outbreak of war. A representative example of this tendency is the design of a guesthouse for Judy Schaffer in Tatarów from 1938 [DAIFO, ref. no. 2650]. The cubic, multi-storey block with a logical window arrangement is topped with a traditional high roof with dormers. Modest elevations with regular arrangement of window openings are composed symmetrically with respect to the axis.

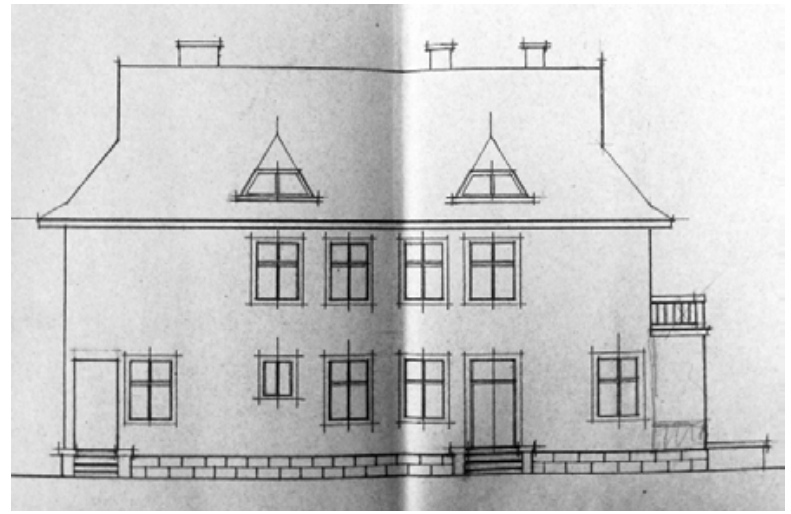

Fig. 15. Max Zucker. Project for extension of the guesthouse of Włodzimierz Uhryn in Jaremcz-Jamna, 1939 (DAIFO, ref. no. 2651)

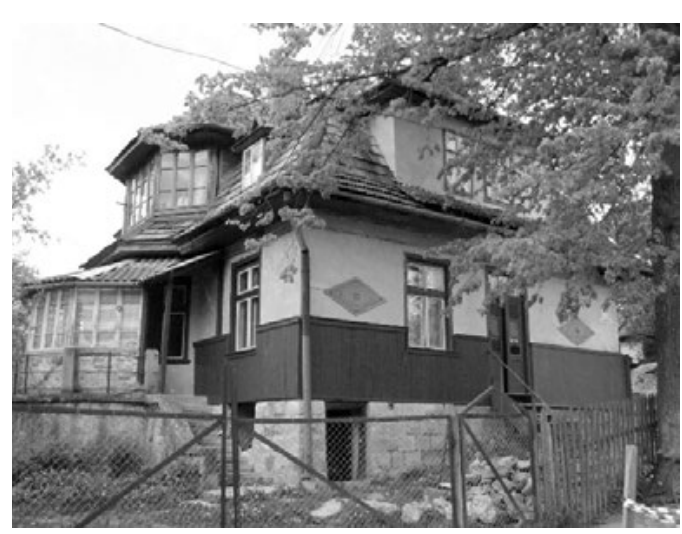

Fig. 16. Jaremcze. House of Max Zucker at ul. Liepkowa 1. Photo.: Jacek. Czubiński, 2011

Similar features are found in a project for the extension of the villa for Włodzimierz Uhryn in Jaremcze-Jamna from 1939 [DAIFO, ref. no. 2651]. The building is covered with a high Dutch gable roof. The northern entrance façade is characterized by the simplicity of the composition (Fig. 15). On the other hand, in the south elevation, the horizontality of the ground floor part is emphasized by the horizontal line of the first-floor terrace. The design provided for a glass dining room on the ground floor with a semi-circular projection.

Also, several other designs can be attributed to Max Zucker. Most probably, he designed his own house in regional stylistics in Jaremcze (Fig. 16). It is a one-storey building with a steep roof with dormers. On the axis of the garden elevation, there is a semi-circular terrace. In the roof area there is a glazed veranda based on a trapezoidal projection. Its form is similar to the multi-storey verandas in the former guesthouse "Liliana" in Worochta. This feature, as well as other formal analogies, may indicate that the guesthouse was also designed by Zucker. Several objects with modernist features also show a formal connection with Zucker's work. For example: known only from the archival iconography, the "Palace" guesthouse in Jaremcze. and the existing building of the "Majestic" guesthouse is also located in this town. At the current stage of research, their authorship cannot be unambiguously determined.

\section{Characteristics of the work of Max Zucker}

Analysing the preserved archives, we notice distinct changes in the style of Max Zucker's work. In 1930, the historic formal extension of the Hanusa hotel took place. In the later period of professional activity, designs with regional characteristics were created, for example a guesthouse for Lankosz in Jaremcze-Jamna from 1930. The breakthrough in his works seems to be the designs of "Gena" and "Przystań" guesthouses from 1932. The architect employed elements from catalogue of modernist forms. This trend was developed most fully in the unrealized design of a guesthouse designed for Moros and Józef Schaffer in Tatarów in 1937. Regional forms were present throughout his professional life. He created, among others, designs in two versions, regional and modernist - guesthouse for Schaffers in Tatarów and house of Pepi Lappowa from 1937. The bathing facility building for dr Matuszewski in Jaremcze combines modernist forms with classicism [Pszczółkowski 2014, pp. 
198-214]. The work from the late 30s was an attempt to reconcile regionalism with modernism and create a synthesis of these tendencies - the villa of Włodzimierz Uhryn in Jaremcze-Jamna from 1939.

Despite the great diversity, buildings with regional features represented a tendency generally referred to as the Hutsul style [Briulow 1996, pp. 55-56]. Its determinants included: axiality and symmetry of the composition, high, sometimes mansard roofs with dormers, entrance porticos, exterior multi-storey verandas, stone pedestals and traditional design of carpentry elements and architectural details. The architecture of regional features created by Zucker compiled different stylistic tendencies in an eclectic way. It cannot be unambiguously assigned to any trend. There are visible influences of both the Zakopane style and the Galician style (Zakopane method) created by Edgar Hovárt based on culture of Zakopane [Tondos 2004, pp. 85-92]. There are also features of the Hutsul - Zakopane style (Polish-Ukrainian) propagated by the Lviv architectural environment [Lewicki 2005, p. 233].

Designs and realizations related to modernism form a cohesive group with common features. The buildings were usually several-piece compositions of rectangular blocks. The most common type were two-storey buildings, sometimes with a small third storey in the form of a belvedere. They were distinguished by almost flat roof with large eaves. Stone walls with a bolt construction were erected on stone pedestals with a visible arrangement of cuts. Reinforced concrete was used in terrace tiles and stairwells. Elevations were characterized by symmetry and geometric arrangement of simple forms. There were verandas, sometimes two-storey with pillars, corner windows, loggias, and roof terraces. Outer walls were plastered white or creamy. Terraces and balconies were secured with simple balustrades made of horizontal steel bars painted in orange. We can see elements of the naval style in the form of rounding of terraces, balconies and whole parts of buildings. The sharp triangles of the attic gable of the "Gena" guesthouse coincide with the simplified "zig-zag" motif and may point to connection with the art déco architecture [Olszewski 2013, pp. 37-45].

One should not underestimate the regional trend in Max Zucker's designs. However, we should particularly emphasize the essence of his work related to modernism. He can be considered an informal creator and a consistent implementer of the phenomenon aimed at determining the identity of Hutsul modernist architecture.

\section{Literature and sources}

[1] Briulow J., Secesja we Lwowie, Warszawa.

[2] Czubiński J., Przykłady modernizmu w murowanej architekturze uzdrowiskowej miejscowości Worochta i Tatarów na Huculszczyźnie - zarys problematyki, [w:] Teka Komisji Architektury, Urbanistyki i Studiów Krajobrazowych, PAN o. w Lublinie, t. IV A, 2008, s. 174-195.

[3] Lewicki J., 2005, Między tradycja a nowoczesnością. Architektura Lwowa lat 1893-1918. Warszawa.

[4] Olszewski A. K., 2013, Art déco i lata trzydzieste w Ameryce a sztuka europejska, Warszawa.

[5] Państwowe Archiwum Iwano-Frankiwskiej Oblastii w Iwano-Frankiwsku (DAIFO); szereg pozycji, różne sygnatury).

[6] Pszczółkowski M., 2014, Architektura użyteczności publicznej II Rzeczypospolitej 1918-1939. Forma i styl, Łódź.

[7] Tondos B., 2004, Styl Zakopiański, Ossolineum, Wrocław.

[8] Yad Vashem - Pages of Testimony Names Memorial Collection, https://yvng.yadvashem.org/ 